\title{
Micropropagation of Rubus spp.
}

\author{
ÅKE FINNE \\ Department of Horticulture, University of Helsinki, \\ SF-00710 HELSINKI, Finland
}

\begin{abstract}
Rapid micropropagation of 'Black Satin', 'Thornless Evergreen' and 'Bedford Giant' was achieved by culturing shoot tips in a 1/1 MS. The best medium in the introduction stage contained $2.0 \mathrm{mg} / \mathrm{l}$ BAP. Shoot proliferation occurred with $3.0 \mathrm{mg} / \mathrm{l}$ BAP. Some problems with callus and phenolic compounds appeared in both introduction and shoot multiplication stages. The plantlets were rooted either in $1 / 10 \mathrm{MS}$ without hormones or directly in peat. Two months later most of 'Black Satin' and 'Bedford Giant' and about half of 'Thornless Evergreen' were growing steadily. Theoretically it is possible to produce 60,000 plants within a half year by this method.
\end{abstract}

Index words: Rubus spp., micropropagation, shoot tip, callus, phenolics.

\section{Introduction}

There is a growing interest towards blackberries, especially varieties that suit small home gardens. The department of horticulture decided to start experiments to find suitable blackberry cultivars. Therefore a research project on rapid micropropagation was carried out at the department. Furthermore we had only one mother plant of one interesting variety, 'Black Satin', but the requirement of plants for future experiments was considerable. Some growers are also interested in rapid propagation of thornless blackberries, 'Thornless Evergreen'. A third variety, 'Bedford Giant', was chosen, because this had been a good performer in the open field.
George and Sherrington (1984) state that because Rubus belongs to Rosaceae family it can be assumed that propagating methods used for apples, roses and strawberries can probably be adapted also for blackberries.

\section{Materials and methods}

Three different varieties of blackberry $(R u$ bus spp.), 'Thornless Evergreen', 'Black Satin' and 'Bedford Giant' were micropropagated.

The material was taken at the end of October 1985 directly from the open field, except 'Black Satin' which was growing in the greenhouse. The leaves were stripped and the shoots were cut into circa $2 \mathrm{~cm}$ nodes. All three varie- 
ties were sterilized for a half minute in $70 \%$ alcohol, 12 minutes in $5 \% \mathrm{NaOCl}$ and rinsed three times in deionized, sterile water. The outside leaf primordia were erased from the axillary buds and the small shoot tips (about $1 \mathrm{~mm}$ size) were transfered to a nutrient medium.

The nutrient medium was full strength MS (Murashige and SKoOG 1962) containing vitamins (niacin $0.5 \mathrm{mg} / \mathrm{l}$, thiamine $0.4 \mathrm{mg} / 1$, pyridoxine $0.5 \mathrm{mg} / \mathrm{l}$, glycine $2.0 \mathrm{mg} / \mathrm{l}$, mesoinositol $100 \mathrm{mg} / \mathrm{l}$ and adenine sulphate 80 $\mathrm{mg} / \mathrm{l})$ and $0.7 \%$ agar and $3 \%$ sucrose $(\mathrm{pH}$ 5.7). In stage I hormones were either $2.0 \mathrm{mg} / 1$ BAP plus $0.1 \mathrm{mg} / 1$ NAA (SKIRVIN et al. 1981) or $2.0 \mathrm{mg} / 1 \mathrm{BAP}$. In stage II $3.0 \mathrm{mg} / 1 \mathrm{BAP}$ was used. The plantlets were rooted either in $1 / 10 \mathrm{MS}$ without hormones or directly in peat.

In the growing room daylength was $16 \mathrm{~h}$ with light intensity at 2000 lux and temperature $25-28^{\circ} \mathrm{C}$.

\section{Results and discussion}

\section{Introduction stage}

Sterilization in the introduction stage was succesful. Only a few 'Thornless Evergreen' were contaminated. BAP $(2.0 \mathrm{mg} / \mathrm{l})$ was obviously better than BAP $(2.0 \mathrm{mg} / \mathrm{l})+\mathrm{NAA}$ $(0.1 \mathrm{mg} / \mathrm{l})$. Callus was a problem on those media that included auxin. (Adventitious shoot proliferation from callus was not desirable.) 'Black Satin' produced considerable callus on the latter medium, which totally prevented shoot elongation and proliferation. A few 'Thornless Evergreen' and 'Bedford Giant' were able to form one shoot per shoot tip in spite of callus formation.

For the medium composing only BAP the case was otherwise. Neither 'Black Satin' nor 'Bedford Giant' formed callus. Shoot formation of both varieties on introduction medium was good (Table 1). 'Thornless Evergreen', however, produced as much callus as on the other medium. No shoot multiplication occurred and only a few shoots could be transfered (rescued) to the multiplication medium.
Table 1. Differences between the media BAP and BAP + NAA for 'Black Satin' (BS), 'Bedford Giant' (BG) and 'Thornless Evergreen' (TE).

\begin{tabular}{|c|c|c|c|c|}
\hline \multirow[t]{3}{*}{ Cultivar } & \multicolumn{4}{|c|}{ Introduction medium ${ }^{1}$} \\
\hline & \multicolumn{2}{|c|}{$\begin{array}{l}\text { Number of shoots } \\
\text { per medium }\end{array}$} & \multicolumn{2}{|c|}{ Callus $^{2}$} \\
\hline & $\begin{array}{l}\text { BAP } \\
(\max / \min )\end{array}$ & $\begin{array}{l}\mathrm{BAP}+ \\
\mathrm{NAA}\end{array}$ & BAP & $\begin{array}{l}\text { BAP + } \\
\text { NAA }\end{array}$ \\
\hline BS & $\begin{array}{l}12 \\
(24 / 1)\end{array}$ & 1 & 0 & $\operatorname{ccc}$ \\
\hline BG & $\begin{array}{l}6 \\
(16 / 2)\end{array}$ & 1 & 0 & $\mathrm{cc}$ \\
\hline TE & $\begin{array}{l}0.5^{3} \\
(2 / 0)\end{array}$ & $0.5^{3}$ & $\operatorname{ccc}$ & $\operatorname{ccc}$ \\
\hline
\end{tabular}

10 media/variety (6 BAP + NAA \& 4 BAP)

2 callus occurrence was marked by following scale: $0=$ no callus, $\mathrm{c}=$ little $(0<2 \mathrm{~mm}), \mathrm{cc}=$ some $(2<0<5 \mathrm{~mm})$, $\mathrm{ccc}=$ much callus $(0>5 \mathrm{~mm})$

${ }^{3}$ only a few could be rescued from wcallus death"

Table 2. Multiplication rate and rooting response for 'Black Satin' (BS), 'Bedford Giant' (BG) and 'Thornless Evergreen' (TE).

\begin{tabular}{|c|c|c|c|c|c|}
\hline \multirow[t]{3}{*}{ Cultivar } & \multirow{2}{*}{\multicolumn{3}{|c|}{$\frac{\text { Multiplication medium }}{\begin{array}{c}\text { Number of shoots/ } \\
\text { medium }\end{array}}$}} & \multicolumn{2}{|c|}{ Rooting } \\
\hline & & & & \multirow[t]{2}{*}{$\begin{array}{c}\text { In } \\
\text { vitro }\end{array}$} & \multirow[t]{2}{*}{$\begin{array}{c}\text { In } \\
\text { vivo }\end{array}$} \\
\hline & $x$ & $\begin{array}{c}\max / \\
\min \end{array}$ & $\begin{array}{c}\text { phenolic } \\
\text { death }\end{array}$ & & \\
\hline BS & 9.3 & $19 / 3$ & $>0 \%{ }^{2}$ & $80 \%$ & $80 \%$ \\
\hline BG & 14.2 & $41 / 0$ & $>30 \%$ & $27 \%$ & $80 \%$ \\
\hline TE & 11.2 & $25 / 2$ & $>50 \%$ & -3 & $47 \%$ \\
\hline
\end{tabular}

\section{$10 \mathrm{media} /$ variety}

2 none dead because of phenolics, but on average 10 (about half) of the shoots/test tube were dead

'TE' was not rooted in vitro

\section{Shoot multiplication}

Full strength MS containing $3 \mathrm{mg} / \mathrm{l}$ BAP was used as a multiplication medium. However some scientists, for example PyotT and Converse (1981), have had fine results with more dilute nutrient concentrations.

Good multiplication took place for all varieties (Table 2). 'Thornless Evergreen' gave 11.2 shoots per medium on average $(\max 25, \min$ 2 shoots/medium), 'Bedford Giant' made 14.2 $(\max 40, \min 0)$ and 'Black Satin' made 9.3 ( $\max 19, \min 3)$ shoots/medium. Increase in 
shoot length was best for 'Black Satin', where most of the shoots were over $1 \mathrm{~cm}$. On the other hand most of the shoots of 'Thornless Evergreen' were short, about $0.5-1.5 \mathrm{~cm}$. Furthermore there were a lot of small shoots which were impossible to count. Popov and SHEHELKUNOVA (1973) have induced increased shoot length using $\mathrm{GA}_{3}$.

\section{Problems with phenolics}

All varieties secreted phenolics, which caused browning and coloured the media a deep yellow tone. Broome and ZimmermanN (1978) have reported similar problems.

For 'Thornless Evergreen' this was a real problem, because almost half of the plants on multiplication medium were in a very bad condition. Also for 'Bedford Giant' this was a problem - about $1 / 3$ died on multiplication medium. 'Black Satin' secreted phenolics too, but no plant in the test tube died even if some shoots were dead. With frequent transfer to fresh media it is possible to control this problem (Broome and Zimmermann 1978).

\section{Rooting}

'Bedford Giant' and 'Black Satin' were rooted both in vitro and in vivo (extra vitrum), whilst 'Thornless Evergreen' was rooted in peat only. The percentage of in vitro-rooting was 27 for 'Bedford Giant' and 80 for 'Black Satin' (Table 2), but only $40 \%$ of the 'Black Satin'-plants had roots longer than $5 \mathrm{~mm}$. SKIRVIN et al. (1981) have reported about spontaneous rooting on multiplication media. This did not occur in this experiment.
Direct rooting occurred on unsterilized peat in peat pots $\left(\right.$ Finnpots $^{\circledR}$ ), under plastic and without hormone treatment. This succeeded well. About two months later the plants were re-potted. At this moment $80 \%$ of both 'Black Satin' and 'Bedford Giant' and $47 \%$ of 'Thornless Evergreen' were in full vigour (table 2).

'Thornless Evergreen' showed a poorer rooting response than the other varieties. This could partly have been due to the fact the that microcuttings of 'Thornless Evergreen' were smaller than the others. Many scientists have had better rooting results by using larger explants (Donnely and Daubeny 1986).

\section{Conclusions}

In spite of difficulties with callus and phenolics, micropropagation of Rubus spp. seems relatively easy and effective. Take 'Black Satin' as an example: A year ago our department had only one mother-plant - now it is possible to begin even more extensive experiments.

Theoretically one 'Black Satin' shoot tip on an introduction medium gives 12 shoots. A further four cultivations after each other on multiplication media increases the plant number to about 75,000 shoots. A rooting- $\%$ of 80 gives 60,000 plantlets - all this within a half year. SNIR (1981) has estimated that 50,000 plantlets/meristem tip/year can be produced.

Acknowledgements. I thank Tapani Haapala and Seija Haalvă for their valuable assistance.

gation by Tissue Culture. Handbook and Directory of Commercial Laboratories. p. 458-459. England.

Murashige, T. \& Skoog, F. 1962. A revised medium for rapid growth and bio assays with tobacco tissue cultures. Phys. Plant. 15: 473-497. 
Popov, Y.G. \& Shchelkunova, S.E. 1973. (The regeneration of Rubus idaeus shoot apices in vitro in relation to the presence of growth substances in the nutrient medium.) Botanichskii Zhurnal 58 (10): 1515-1520. In George and Sherrington 1984.

Pyotr, J.L. \& Converse, R.H. 1981. In vitro Propagation of Heat-treated Red Raspberry Clones. HortSci. 16 (3): 308-309.

\section{SELOSTUS}

\section{Karhunvatun (Rubus spp) mikrolisäys}

\section{Åke Finne}

Puutarhatieteen laitoksella on lisätty mikrolisäysmenetelmällä kolmea karhunvattulajiketta, (Rubus spp) 'Thornless evergreen', 'Black Satin' ja 'Bedford Giant'. Paras aloitusalusta oli $1 / 1 \mathrm{MS}$, joka sisălsi $2.0 \mathrm{mg} / \mathrm{l}$ BAP:a. Jakoalustassa käytettiin $3.0 \mathrm{mg} / 1$ BAP:a. Kallusja fenoliongelmia esiintyi hiukan kummallakin alustalla. Mikrokasvit juurrutettiin joko 1/10 MS-alustalla ilman
SNIR, I. 1981. Micropropagation of red raspberry. Scientia Hortic. 14: 139-143.

SkIRvin, R.M., Снu, M.C. \& Comez, E. 1981. In vitro Propagation of Thornless Trailing Blackberries. HortSci. 16 (3): 310-312.

Ms received September 19, 1986.

hormooneja tai ne pistettiin suoraan turvealustalle. Noin kaksi kuukautta myöhemmin suurin osa sekä 'Black Satin'- että 'Bedford giant'- ja noin puolet 'Thornless Evergreen'-lajikkeiden taimista kasvoivat hyvin. Teoreettisesti tăllä menetelmăllă voidaan puolessa vuodessa tuottaa 60.000 tainta. 